\title{
FAIRS OF SCIENCE AS ENCOURAGEMENT TO THE DEVELOPMENT OF ENVIRONMENTAL PERCEPTION OF ELEMENTARY AND HIGH SCHOOL STUDENTS
}

\author{
M. S. RUIZ ${ }^{1}$, C. C. QUARESMA ${ }^{1 *}$, A. B. dos SANTOS ${ }^{1}$, I. OGASHAWARA ${ }^{2}$, M. L. FERREIRA ${ }^{1}$ e T. T. P. CORTESE $^{1}$ \\ ${ }^{1}$ Universidade Nove de Julho - UNINOVE \\ ${ }^{2}$ Indiana University-Purdue University Indianapolis \\ quaresmacc@yahoo.com.br*
}

Article submitted in December/2015 and accepted in May/2016

DOI: $10.15628 /$ holos.2016.3902

\section{ABSTRACT}

The definition of environment, which disregard the changes resulting from historical progressive rupture of man in relation to his surroundings, is one of the conceptual errors that hinder the understanding and solution of environmental problems of the present. Such difficulties are deepened by the extreme specialization of knowledge that undermined the understanding of environmental problems, making critical analysis urgent and able to integrate different areas of knowledge. Science and technology fairs can be seen as important initiatives to this integration. Thus, this study aimed to verify the perception of students participating in Febrace (Brazilian Science and Engineering Fair) in relation to the
\end{abstract}

environment and the impacts of this fair in raising awareness about that issue. This is a quali-quantitative research based on bibliographic and documentary surveys and interviews with primary and secondary students who were responsible for the projects presented in that fair. The results showed that the majority of respondents (over 74\%) have a more elaborate and globalizing vision of the concept of environment. It was also found that, in general, interviewed students could observe positive influences of the fair on their environmental perception and felt more interested and motivated to understand and discuss environmental problems.

KEYWORDS: Youth Science; FEBRACE; Environment.

\section{FEIRAS DE CIÊNCIA COMO ESTÍMULO AO DESENVOLVIMENTO DA PERCEPÇÃO AMBIENTAL DOS ESTUDANTES DO ENSINO FUNDAMENTAL E MÉDIO}

\section{RESUMO}

A definição de meio ambiente, que desconsidere as transformações resultantes da histórica ruptura progressiva do Homem em relação à natureza, implica em erros conceituais que dificultam o entendimento e a solução de problemas ambientais atuais. Além disso, a extrema especialização do saber compromete o entendimento dos problemas ambientais, tornando urgentes análises críticas, capazes de integrar diferentes áreas do conhecimento. Os eventos de ciência jovem podem ser vistos como importantes iniciativas à esta integração. Assim, o presente trabalho objetivou verificar a percepção em relação ao meio ambiente de alunos participantes da Feira Brasileira de Ciências e Engenharia, bem como os impactos desta feira na conscientização dos mesmos em relação ao referido tema. A presente pesquisa é de natureza quali-quantitativa fundamentada em levantamentos bibliográfico e documental, além de entrevistas à estudantes do ensino fundamental e médio, participantes da FEBRACE no ano de 2013. Os resultados demonstraram que a maioria dos entrevistados (mais de $74 \%)$ possui uma visão mais elaborada e globalizante do conceito de meio ambiente. Verificou-se também que, de maneira geral, os alunos entrevistados observaram influências positivas da feira em sua percepção ambiental e se sentiram mais interessados e motivados no entendimento e na discussão dos problemas ambientais.

PALAVRAS-CHAVE: Ciência Jovem; FEBRACE; Meio Ambiente. 


\section{INTRODUCTION}

The correct understanding of environmental problems depends on the proper definition of the concept of environment ("meio ambiente"), which is hampered by its widespread use and various meanings applied to both terms ("meio" and "ambiente"), in the academic field and in journalism. According to Christofoletti (1999), taking into account that the term environment has been applied to issues ranging from the global magnitude of scale to the punctual micro scale, to the context of environmental issues, there is the need for greater precision in the definition of the used concepts.

In this sense, the environment definition that disregard the changes resulting from the historical progressive rupture of Man in relation to his surroundings, is one of the misconceptions that hinder the understanding and solution of environmental problems of the present (Santos, 1995).

Such difficulties are deepened by the extreme specialization of knowledge that, despite allowing significant scientific and technological advances, committed the understanding of environmental problems, they started lacking totalizing and capable analysis to integrate different knowledge areas, inherent to a legitimate interdisciplinary work (Santos, 1995).

Science and technology fairs for students of primary, secondary and technical schools, conducted by universities, non-governmental groups, public and private schools of the Brazilian educational system, which aim to encourage the development of research projects based on scientific methodology, can be seen as important initiatives to this integration.

In the context of all these fairs, young people are given the opportunity to be the main actors in the implementation of a pedagogical innovation aimed at a network of learning from the project methodology. In this, confrontation and negotiation between participants allow the collective construction of knowledge or new technological knowledge (Nascimento, 2012). It is in this sense that the science and engineering fairs empower young people's engagement to the scientific culture, making them the protagonists of their learning.

The youth science movement corroborates this thought because it aims to encourage scientific research from basic education, through the promotion of events such as science fairs and exhibitions for papers presentations by students and teachers of early childhood education and/or primary or secondary education in public and private schools. These research projects, which cover any area of knowledge or connect different areas, have their results presented in the form of reflective recording of teaching practices experienced by students with teachers and posters, with the following goals: (i) encourage reflection about the teaching-learning process in science education; (ii) socialize the experiences in the context of science education; and (iii) encourage the development of science education teaching practices in different areas of knowledge such as biological, social , human and natural (Espaço Ciência, 2014).

Given the importance of science fairs and exhibitions, as well as the expected potential of students participating in them, this work aimed to study the perception of FEBRACE (Brazilian Science and Engineering Fair) among participating students in relation to the environment, as well as the impact of this fair in their environmental awareness. For such, we sought to: (i) evaluate the understanding of the environmental concept of the fair participants; (ii) check that participants' 
understanding of the relationship between their projects and environmental issues; (iii) check whether they were able to identify the representation of environmental projects in relation to the total of projects submitted; (iv) assess whether the students perceived positive influences of the fair on their awareness of the environment; and ( $v$ ) observe how participants interpret a specific environmental problem.

\section{LITERATURE REVIEW}

\subsection{Science Fairs}

Science fairs were originally designed in 1921 by William Emerson Ritter and Edward W. Scripps as a news service, nonprofit activity, the "Science Services", in order to keep the public informed of the latest advances in science. Later, these researchers, when collaborating with Westinghouse, established in 1942, "The Science Talent Search," a competition to encourage secondary students to identify an area of interest for the development of their professional careers in science or engineering (Choi, 2015).

In Brazil, the need to undertake collective efforts to improve the educational indicators led the National Council for Scientific and Technological Development (CNPq) and the Higher Education Personnel Improvement Coordination (CAPES) to establish partnerships with various educational and scientific institutions, to propose the holding of fairs and scientific exhibitions at national, state and municipal levels. It is a mechanism aimed at strengthening the involvement of students and educators in a project that improves the learning process and scientific research conducted in Brazilian schools (CNPq, 2015).

In this sense, the creation, in 2005, of the National Program to Support Science Fairs in Basic Education (FENACEB) by the Ministry of Education, was an important milestone to encouraging regional fairs in the country. As the program support tool, CNPq created the Science Fairs and Scientific Shows Public Notice, published annually, which aims to support the holding of science fairs at national, state and municipal/district levels, aiming at improving primary, secondary and technical school and, also, to awaken the scientific and/or technological vocations and encourage talented young people to pursue scientific and/or technological careers (CNPq, 2012).

In addition to these fairs, there are others which are not covered by that public notice, but are held annually, of which can be cited: (i) Science, Technology and Innovation Fair of Rio de Janeiro (FECTI), which takes place since 2006; (ii) Brazilian Science and Technological Fair / International Science and Technological Fair (MOSTRATEC), held annually by Liberato Foundation in Novo Hamburgo-RS, which shows research projects in various areas of knowledge, carried out by young people in secondary and technical education from different countries; and (iii) Ciência Jovem, one of the four largest fairs in Brazil, it is promoted by Espaço Ciência and reaches the entire metropolitan region of Pernambuco and other states located mainly in the Brazilian Northeast Region.

The FEBRACE has an intermediate position in this respect, because although they count on the support of the CNPq Public Notice, they did not receive such aid at the beginning of their activities. This fair is organized by the Polytechnic School of the University of São Paulo, in order to gather students of the 8th and 9th grades of the primary school, and also secondary technical education students, who are not older than 21 years old. It is an annual fair, inspired by 
international fairs, which involves student projects from public and private schools throughout Brazil, in several Science categories (Exact and Earth, Biology, Health, Agricultural, Social and Humans), Engineering and its Applications (FEBRACE, 2005).

FEBRACE's main objectives are to encourage new vocations in science and engineering through the development of creative and innovative projects, and align public and private schools to universities, creating spontaneous interaction opportunities between students and schools teachers with the university community (university students, faculty and staff) for a better understanding of the roles of universities in education, research, culture and extension (FEBRACE, 2005).

In general, science fairs and shows have proven to be a high-impact strategy, linking teachers and students in the production of knowledge, sharing information and incorporating scientific research attitudes that contribute to the construction of learning. The support to science fairs and shows, at national, state and municipal level is, therefore, an investment in the improvement of primary, secondary and technical education, as well as an effective mechanism to awaken scientific and technological vocations and the interest of talented young people by careers in these areas (CNPq, 2015).

In addition, fairs and science shows allow a diagnosis of how teaching and learning has been developing throughout Brazil, this way allowing a more appropriate intervention aimed at establishing a dialogue between students, teachers, parents and administrators, and improving the general conditions of education (CNPq, 2015).

\subsection{Environment Concept}

According to Silva (2008), the origin of the expression "environment" (in Portuguese, environment means 'meio ambiente', which literally translates to 'meio', the 'medium' and 'ambiente', 'environment') can be attributed to the French naturalist Geoffrey Saint-Hilaire, who, in his work Etudes progressives dún naturaliste, published in 1835, defines medium (milieu) as the place where a living being belongs and moves in, and environment (ambiance) as the conditions surrounding these beings.

Some authors criticize the use of the Portuguese term "meio ambiente", they consider it to be redundant, since, as it is employed, both words mean the same thing. For these authors, using the term "ambiente" is enough and more suitable (Silva, 2008).

Other authors, however, as Milaré (2001 as cited in Silva, 2008), qualifies this discussion as a simple matter of semantics, which is meaningless, given that the term environment is longstanding in Portuguese and is used by doctrine, law and jurisprudence of Brazil, as well as acronyms of international, national, state and local agencies, such as UNEP, Ministry of Environment and Secretariats for the Environment.

However, despite the diffusion and acceptance of the term, the inherent discussion about its correct use and the concept attributed to it is indispensable, since the choices express different meanings and carry content that reflects different views of the world, with political, cultural and socioeconomic nuances. In this sense, Christofoletti (1999) points out that the world view prevailing in every civilization throughout history implies the significance and appreciation of the environment, reflecting the several forms of relations of the environment and Man. 
However, the proper definition of the term environment (ambiente) comes up against the widespread use of the term in the academic and journalistic field. Thus, this term has been applied to issues ranging from the global magnitude of scale to the point of micro scale, it can relate to terrestrial environment, lacustrine environments, plant, animals and men environments, work environment, social environment, cultural environment, family environment and opportunities environment. The word is the same, but meanings and the expressiveness of the phenomenon are different, and, depending on its application, it can lead to gross misconceptions (Christofoletti, 1999).

However, for the context of environmental problems, it is necessary to use more precise concepts, with statements allowing its functionality through the use of analytical procedures and evaluation criteria. In this sense, Christofoletti (1999) presents two conceptual perspectives. The first one has a social and biological significance, focusing on the context and the circumstances surrounding the human being. This view is present in the definition proposed by Brackley (1988), it states that the environment is the circumstances under which the Man lives. The second perspective considers the interactive functionality of the geosphere-biosphere, focusing on the existence of organizational units comprehending the physical and biotic elements. This way, the term "meio ambiente" is used to represent the geosphere-biosphere set components, consistent with the physical environmental system, or geosystems.

The second perspective mentioned, in the case of Brazil, can be seen in the legal concept of "Meio Ambiente", present in the National Policy for the Environment and noted by Silva (2008), as "the set of conditions, laws, influences and interactions of physical, chemical and biological order, which allows, houses and govern life in all its forms."

It is noted, in this case that the concept of "meio ambiente" is restricted to the natural environment, thus disregarding artificial or constructed environment, and at the same time being out of date in relation to the present reality. In this sense, we agree with Santos (1995), when he points out that when the prisoners of a fixed vision are at risk of being adrift when interpreting the present.

According to Santos (1995) the concept of "meio ambiente" is not different from the concept of 'medium', as discussed by geography and sociology in the late nineteenth century, and that according to authors such as Humboldt, Ritter, Vidal de La Blache and Durkheim, it is considered as an essential element of human life. Thus, damage caused to the environment are also caused to man's way of life, or to the entire medium.

Observing the environment without considering the changes resulting from the historical progressive rupture of man in relation to his surroundings, characterized by an increasing mechanization of the planet, the metamorphosis of nature to an artificial nature and formation of an increasingly technical medium (Santos, 1994), is one of the rough conceptual errors, as mentioned above, and which hinder the understanding and solution to environmental problems of the present.

In this sense, but not at all consistent, Smith (2008) discusses the concept that the environment must be comprehensive, covering the nature and the artificial, or built environment.

The greatest care with the environment definition, approaching it to the current reality and understanding it as the way of life of man and transformed by him, allows greater chances to the 
contextualization of the environmental crisis and to meeting possibilities of action that escape topical studies and seduction of global campaigns, resulting in the proposals of more suitable solutions for the environment (Santos, 1995).

\section{METHODOLOGY}

This is a quali-quantitative research based on bibliographic and documentary surveys and on interviews. For Yin (2003), this type of research allows the convergence of ideas through a process of triangulation of information from different data sources.

Given the proposed objectives and the national representativeness of FEBRACE, the activities provided by the adopted methodology were carried out in this fair. Thus, the literature consisted on the search and analysis of information from articles published in journals, and the documentary survey was based on the 2013 annals of FEBRACE, available in print and digital sources in their website.

Currently, FEBRACE, besides representing a learning experience that goes beyond the limits of curriculum frameworks, motivates creativity and entrepreneurship giving a revelation opportunity for young talents, through the development of projects in various fields of science and engineering.

For the interviews conduction, a questionnaire with six questions was prepared, five semistructured questions and one open question. The five semi-structured questions addressed the following issues: (i) What is the environment? (ii) Is your project related to the environment? (iii) How was the approached problem in your research realized? (iv) How do you evaluate the quantity of projects related to the environment in FEBRACE? (v) After participating in FEBRACE and "experiencing" the diversity of environmental problems approached in the Fair, how will your attitudes and behaviors towards the environment going to be like from now on?

The open question (vi) aimed to verify the interviewed perception in relation to environmental problems pictured by the illustration (cartoon) about a polluted river and fish in a fishbowl thinking "it's safer here", shown in Figure 1.

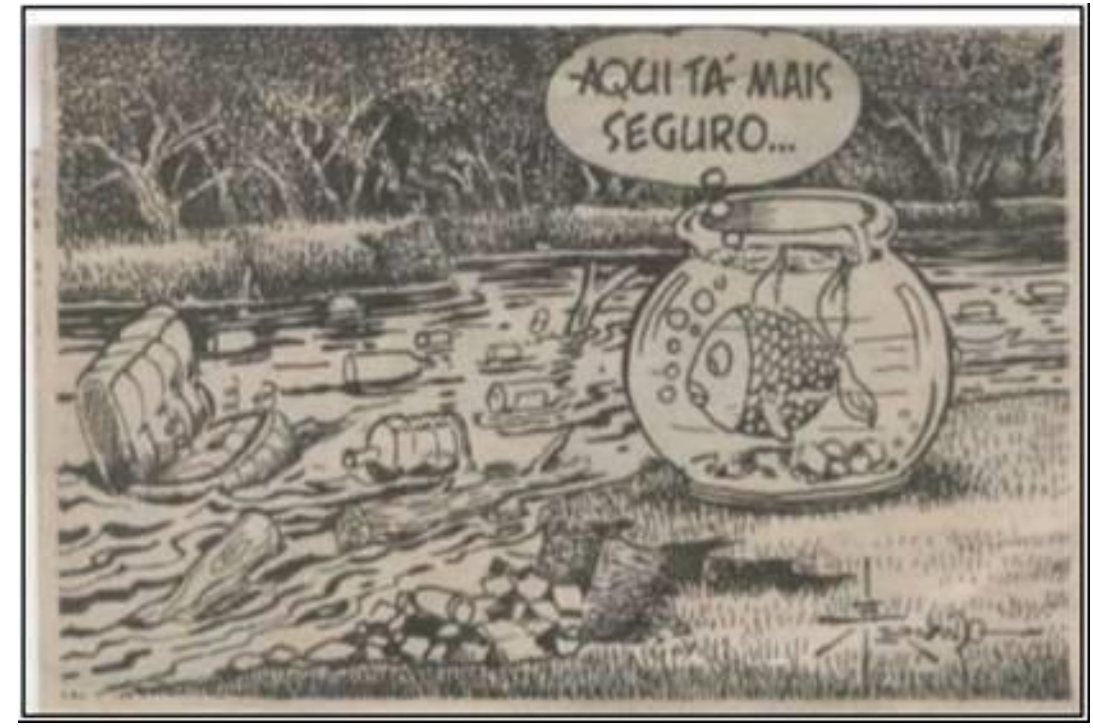

Figure 1: Illustration presented in question 6 in the questionnaire

Source: A Gazeta newspaper (June, 2001, as cited in Ribeiro \& Camargo, 2006) 
According to Ribeiro and Camargo (2006), who used figures and illustrations as a form of raising awareness to the human action on the environment, the intention of using images is the formation of a critical, reflective thinking which contributes to the intellectual, affective and social citizen formation in the understanding of environmental problems. These authors concluded that the ideas put forward on the environment are often misleading and loaded with a naturalistic view. The images, in turn, have an advantage because, when they are produced, they are intended to raise awareness about environmental issues. However, according to the authors, most times, they do not become a reality because they give the idea that humans are not part of the environment, but we are its destroyers.

In face of the proposed objectives, interviews were conducted with students participating on projects related to the environment, on March 12 and 13, 2013, with the approval of the coordinator of FEBRACE, Prof. Dr. Roseli de Deus Lopes. The questionnaire was left at the students' stand and collected about half an hour later.

For the selection of works whose students were interviewed, we used the material provided by the management of the event, a few days before, which bore the titles and rankings separated by areas of knowledge, out of the 330 projects selected.

From this information, it was possible to identify 96 projects related to the environment, distributed by area of knowledge covered by FEBRACE can be observed in Table 1.

Table 1: Amount of projects about the environment presented in FEBRACE in 2013

\begin{tabular}{cc}
\hline Knowledge areas with environment projects & Amount of projects related to the environment \\
\hline Engineering & 25 \\
Exact and Earth Sciences & 21 \\
Biology Sciences & 19 \\
Agricultural Sciences & 11 \\
Human Sciences & 8 \\
Social and Applied Sciences & 7 \\
Health Sciences & 5 \\
\hline Total of projects & 96 \\
\hline & Source: (FEBRACE, 2013)
\end{tabular}

After conducting the interviews, answers were tabulated in Excel spreadsheet to simplify data and information system and development of graphics and use of descriptive statistics. Graphs and statistical analysis allowed the discussion of results.

\section{RESULTS AND DISCUSSIONS}

Documentary research has shown that the 11th edition of FEBRACE, held in 2013, directly involved over 22,500 students from 26 states in Brazil, who developed investigative projects submitted directly to the Fair or through one of the 65 affiliated fairs. In this context, 330 projects were selected for the show, they were presented by 740 graduate students, duly accompanied by 291 advisor teachers and/or co-advisors.

Out of these projects, 96 related to the environment, inserted in the areas of Engineering, Exact and Earth Sciences, Agricultural Sciences, Biology, Health Sciences, Social and Applied Sciences and Humanities. (FEBRACE, 2013). This number represented more than $29 \%$ in relation to the total amount of projects. 
The interviews could be conducted with the students participating in 66 projects among the 96 mentioned, as we can see in table 2.

Table 2: Amount of projects per knowledge area with interviewed students

\begin{tabular}{cc}
\hline Knowledge areas with environment projects & $\begin{array}{c}\text { Amount of projects related to the } \\
\text { environment with interviewed students and } \\
\text { percentage related to total per area }\end{array}$ \\
\hline Engineering & $17(68 \%)$ \\
Exact and Earth sciences & $16(76 \%)$ \\
Biology sciences & $15(79 \%)$ \\
Agricultural sciences & $6(55 \%)$ \\
Human sciences & $5(63 \%)$ \\
Social and Applied Sciences & $4(57 \%)$ \\
Health Sciences & $3(60 \%)$ \\
\hline Total of projects & 66
\end{tabular}

Answers to the first question (what is the environment?) can be observed in Figure 2.

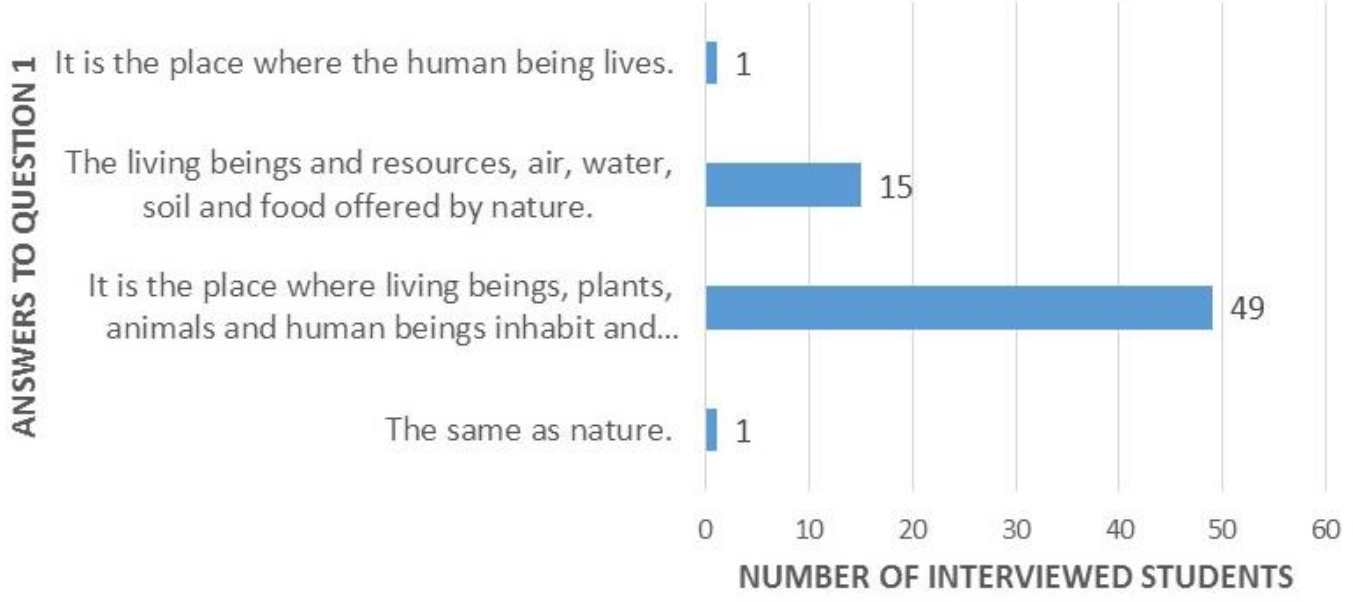

Figure 2: Answers to question 1 - "what is the environment?"

In Figure 2, it was observed that the majority of interviewed students (over $74 \%$ ) have a more elaborate and comprehensive view of the concept of environment, as defined by Silva (2008), considering it as the place where living beings, among which the Man himself, live and interrelate.

Only one student related the concept of environment to nature, demonstrating the vision of a past reality, prior to the social changes materialized in space through the technique, which defined the medium as technical, scientific and informational, characteristic of the current period, as defined by Santos (1995).

About $23 \%$ of respondents answered that the environment can be defined as living beings and the resources that nature offers. This point of view carries concepts related to a theological worldview as defined by Christofoletti (1999), who considers nature as a resource, available to exploitation by the Human Society. The significant percentage of responses in this sense is worrying when it comes to the current environmental problems, since such vision dissociates the middle and the Man, seeing the environment as a resource to be exploited. 
A student pointed that the environment is a place where the human being lives. While revealing the concept of environment as man's space, as pointed by Santos (1995), it reveals a more limited vision, disregarding the other living beings that share this medium.

Figure 3 refers to the responses received to the question that sought to explore if the fair participants realized that their projects related to the environment.

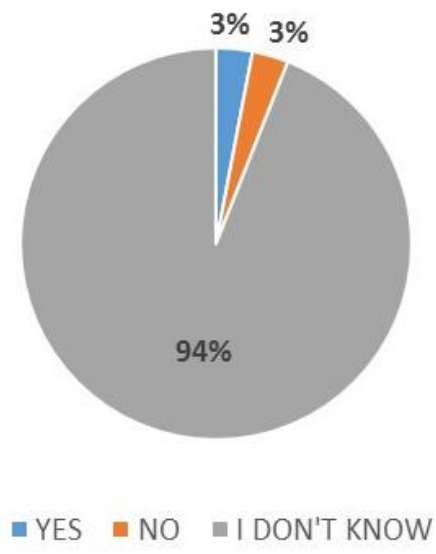

Figure 3: Answers to question 2 - (Is your project related to the environment?)

In Figure 3, it is observed that $94 \%$ of students surveyed perceived the relationship between their projects and the environmental, 3\% could not answer and 3\% said they did not know. These results show that the students, as expected by the Fair objectives, are informed about their projects and the theme treated by them.

Figure 4 shows the result obtained for the question "how was the approached problem in your research perceived?"

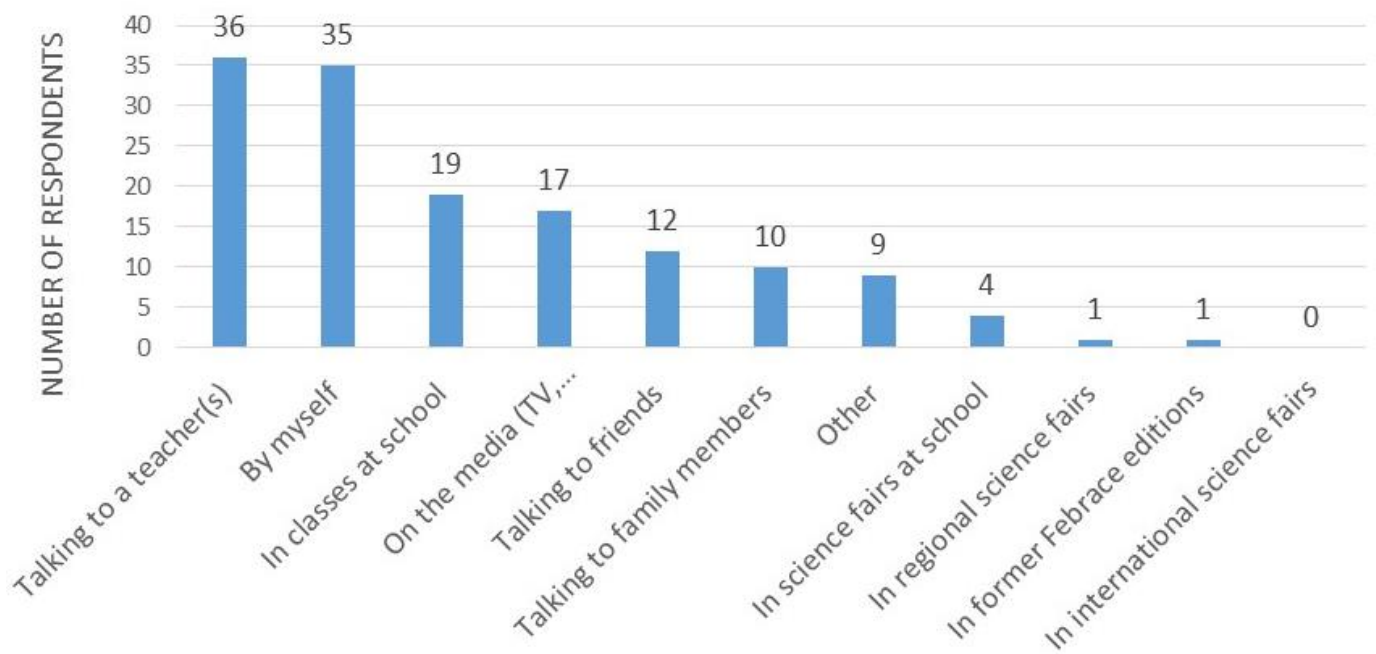

ANSWERSTO QUESTION 3

Figure 4: Answers to question 3 - how was the approached problem in your research perceived? 
When analyzing Figure 4, it was realized that there is a predominance in identifying the problem studied by talking to teachers and by the students themselves participating in classes at school and through written and spoken media.

The results presented in Figure 4, show the strategic role of fairs and science exhibitions, at promoting the union between teachers and students in the production of knowledge, sharing information and the incorporation of scientific research attitudes which contribute to the construction of learning as expected by CNPq (2015).

The results also allow corroborating the claims of CNPq (2015), that the fairs and science shows allow a diagnosis of how teaching and learning is developing in various parts of the country and how the dialogue between teachers and students has been developing.

Also, bringing up issues related to the environment and awareness of environmental problems at school and through written and spoken media is very important, once they constituted important sources for determining research problems approached by the projects.

Figure 5 shows the results of the question on how the participation in FEBRACE and the "experience" with the environmental issues addressed at the fair impact on the environmental perception of the students, enabling a change in attitudes and behaviors.
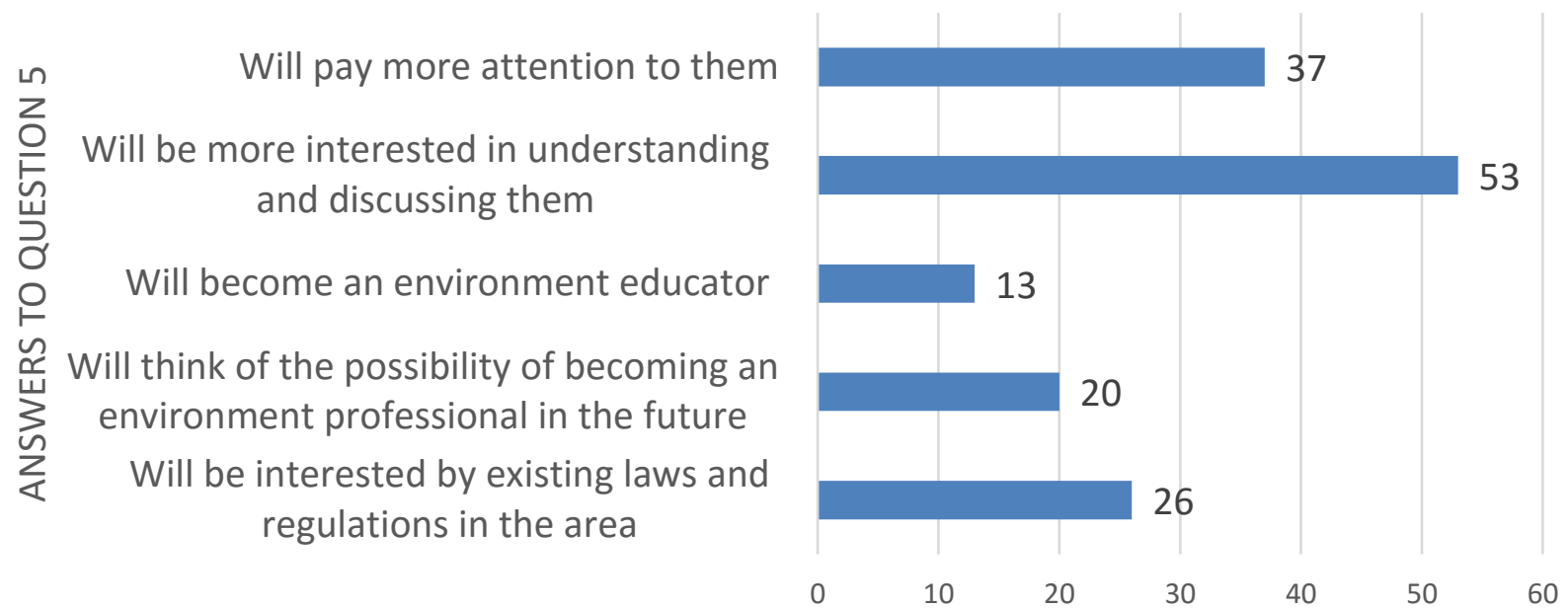

NUMBER OF INTERVIEWED STUDENTS

Figure 5: Answers to question 5 - (How did participating in FEBRACE as a student and the "experience" with the environmental problems presented influence you?)

The analysis of Figure 5 shows that, in general, the students interviewed observed positive influences of the fair on their environmental awareness. In addition, the responses show that respondents felt more interested and motivated to understand and discuss environmental problems.

Figure 6 presents results for the question: how do you evaluate the quantity of projects about the environment in FEBRACE? 


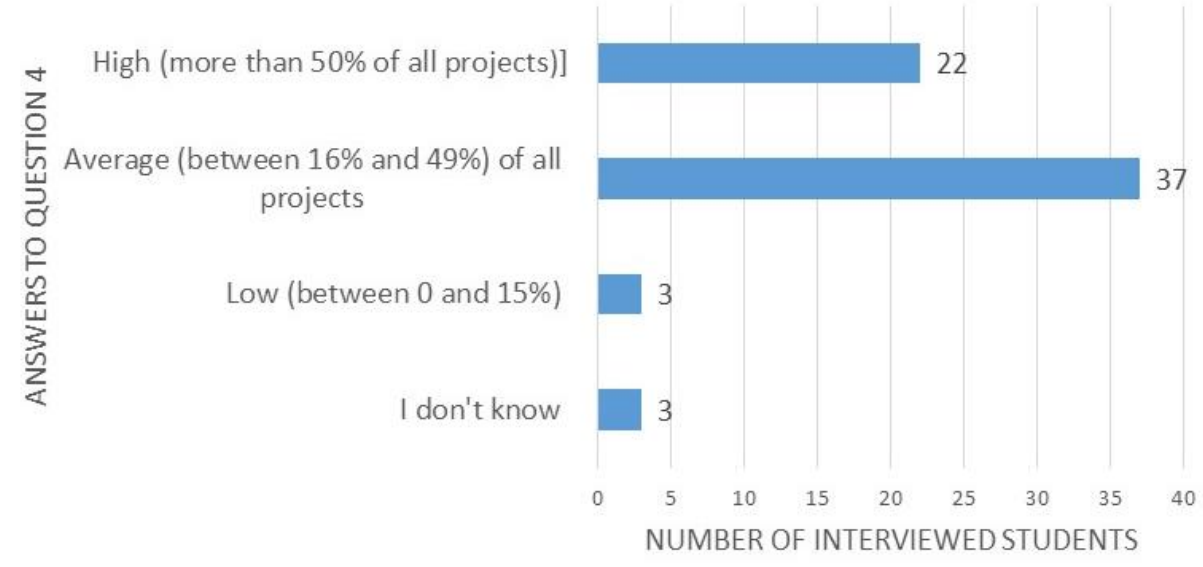

Figure 6: Answers to question 4 of questionnaire which seeks to evaluate the perception of young people about the environment projects

Figure 6 shows that almost 90\% of the interviewed students realized that there was a significant concern of many of the projects presented in relation to environmental issues. As mentioned above, from the 330 projects selected for the event, 96 could be related to the theme 'environment', which is equivalent to a value of approximately $30 \%$. This way, most interviewed students (37) approached the real value when answering that between $16 \%$ and $49 \%$ of the projects selected for the fair related to environmental issues. The fact that the students have perceived this relationship allows us to infer that the projects related to the environment attracted the attention of the participants interviewed when it came to the theme, reaching the expectations appointed by CNPq (2015), for this type of fair.

Regarding the open question, related to the perception of students in relation to environmental issues presented in the illustration, the responses allowed us to classify them into four categories: river pollution; Man's behavior as responsible for causing the pollution; impacts on the natural habitat; and impacts on fish life.

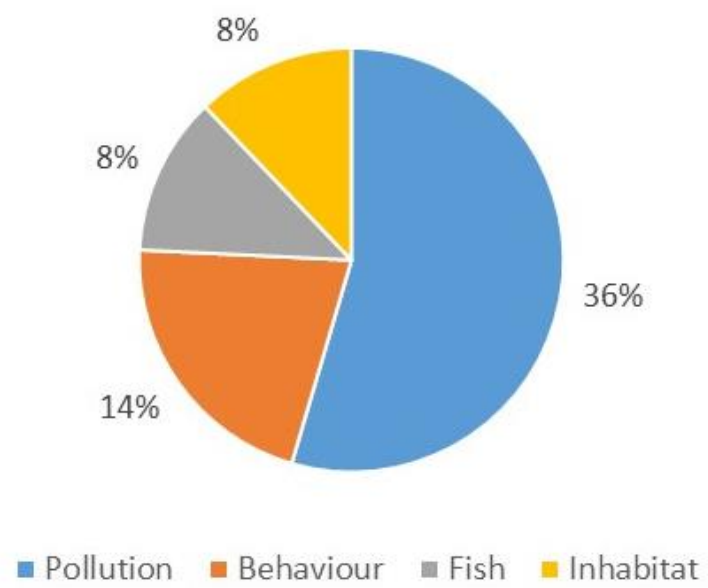

Figure 7: Answers to question 6 of the questionnaire (what does the picture show?)

The results shown in Figure 7 show that all students identified an environmental problem in the illustration, most of them, about $54 \%$, said that it portrayed the pollution of rivers. 
In response to a second open question related to the questionnaire illustration (what does the illustration represent to you?), $54 \%$ of the 66 students interviewed interpreted it as a problem that needs to be solved by man.

In general, Ribeiro \& Campbell (2006) statements could be corroborated when it came to the role of figures and illustrations as a form of raising awareness about human action on the environment, as well as their potential to stimulate critical and reflective thought, contributing to the intellectual, emotional and social citizen formation at understanding environmental problems. Thus, by using illustrations to motivate perception of an important current environmental problem, it was observed that both the illustrative elements and the words contained therein reached students surveyed motivating them to "read" and interpret the cartoon differently, seeing the human being as responsible for environmental degradation and holding them responsible for its recovery.

However, it should be noted that the interpretation of a given image depends on the eye of the beholder and thus their different values and worldviews. Most responses focused on the river pollution problem, impacts on the natural habitat and fish life, reveal that in the interpretation of the environment, the notion of natural medium still prevails, corroborating the observations of Ribeiro and Camargo (2006). In this view, the medium is no longer interpreted as the space of Man, as a result of social relations and as a regulator agent of it. In this view, man is then seen as an external agent in the middle, considered natural, and whose social actions negatively affect the environment, while he is not affected by it.

This limited view of the concept of environment generates, in the words of Santos (1995), current reductive approach, to the extent that they are only interested in one aspect of a complex problem, a purely economic or exclusively natural point of view. Such reductionism implies in the elaboration of misleading causal chains and they can make the effects precede the causes in knowledge production.

In this aspect, youth science is an important tool to combat this reductionist view, once students develop their critical sense as to discuss and seek solutions to their everyday problems. Thus, the popularity of youth science events makes more and more students interested in the construction of knowledge, not just reproducing the same. Therefore, monitoring former participants in youth science events is an important tool for assessing the development of the students critical thinking during primary and secondary education. For example, in the United States, the Society for Science \& the Public has a social network for former participants of the Intel International Science and Engineering Fair (Intel ISEF), which is one of the largest youth science events in the world. This month, with the disclosure of the Chemistry Nobel Laureates, the Society noted that one of the winners, Dr. Paul Modrich, is a former participant of the event, showing that youth science events can contribute to the formation and career of its participants.

\section{CONCLUSIONS}

The concept of environment, which is limited to the natural environment and which disregards the artificial or built environment, shows to be out of date when compared to the reality, resulting in mislead analyzes and interpretations of current environmental problems. Thus, 
the correct way to face environmental problems depends on the proper definition of the environment concept, which should incorporate the changes imposed by man to the medium.

Such definition comes up against the difficulties of integrating the various areas of knowledge, which have gone through processes of extreme specialization of knowledge. In this sense, science and technology fairs for primary, secondary and technical students, belonging to the Youth Science movement, have shown to be important initiatives to this integration, once they motivate students to get involved mostly with interdisciplinary projects, which seek solutions to environmental problems and challenges of their daily lives.

The results from the present study showed that most of the students interviewed, among the participants of FEBRACE, presented a more elaborate and comprehensive view of the environmental concept, considering it as the place where living beings, among which the man himself, live and interrelate. Besides, most part of the interviewed students realized the relation between their projects with the environmental area and observed positive influences of the fair on their environmental perception, saying that they felt more interested and motivated to understand and discuss environmental problems. However, it is important to note that the absence of a control group, made it impossible to conclude the effectiveness of this Youth Science event on the development of critical thinking of its participants.

Another point to note is that, often, the school or advisor already has a youth science project, and students end up just working on existing ideas rather than seeking to observe their daily problems and trying to find a solution for them. The results of the interviews showed that approximately half of the work in the environmental area originated from advisors' ideas rather than from the students' themselves. This is also a criticism to these youth science events system, once teachers seek to win awards and not the students themselves, which can limit the development of students' critical thinking, as they did not participate in the project design.

There was also a lack of studies related to the implementation of Youth Science in Brazilian schools, as well as an assessment of the development of students' critical thinking in primary and secondary school. Reports and proceedings of the Youth Science events is the available information and little is done to monitor the development of the events former participants.

In this sense, it is necessary that non-governmental associations can carry out works such as Society for Science \& the Public, held in the United States. Thus, as a recommendation for future studies, further search in education magazines is suggested, expanding the range of keywords to "Science for Younger" and "Young Scientist". It is noteworthy that this search should take special care so that the term "Youth Science" is not confused with new areas of science. The use of control groups is also recommended, in order to trace the actual development of the students involved with the youth science and also projects that can try to trace the history of former participants of these events in the country.

\section{REFERENCES}

1. BRACKLEY, Peter. Energy and environmental terms. United States: A Glossary. Aldershot: Gower Publishing Co, 1988.

2. BRASIL (2006). Ministério da Educação. Secretaria de Educação Básica. Programa Nacional de Apoio as Feiras de Ciências da Educação Básica - Fenaceb. Brasília, DF: MEC. 
3. CERVO, A. L., BERVIAN, P. A., \& SILVA, R. da. Metodologia Científica. (6a ed.). São Paulo: Pearson Prentice Hall, 2007.

4. CHOOI, J. (2015). Science fairs aren't actually preparing your kids to do anything. Quartz (publication). Recuperado em 09 junho, 2015, de http://qz.com/367007/science-fairsarentactually-preparing-your-kids-to-do-anything/.

5. CHRISTOFOLETTI, A. Modelagem de Sistemas Ambientais. São Paulo: Edgar Blücher Ltda, 1999.

6. Conselho Nacional de Desenvolvimento Científico e Tecnológico - CNPq. (2012). Edital CNPq 50/2012. Recuperado em 09 junho, 2015, de http://www.CNPq.br/web/guest/chamadas publicas?p_p_id=resultadosportlet_WAR_resultadosCNPqportlet_INSTANCE_0ZaM\&filtro=a bertas\&detalha $=$ chamadaDivulgada\&idDivulgacao $=2541$.

7. Conselho Nacional de Desenvolvimento Científico e Tecnológico - CNPq. (2015). Feiras e Mostras de Ciência. Recuperado em 09 jun, 2015, de http://cnpq.br/sobre.

8. ESPAÇO CIÊNCIA. XX Ciência Jovem Regulamento - Educação Científica. Olinda, PE: Espaço Ciência, 2014.

9. Feira Brasileira de Ciências e Engenharia. FEBRACE (2005). Febrace 3 - Criatividade e Inovação. Recuperado em 02 junho, 2015, de http://www.Isi.usp.br/febrace/apresentacao.htm.

10. LOPES, R. de D., FICHEMAN, I. K., \& SAGGIO, E. Febrace11 - Criatividade e Inovação. Feira Brasileira de Ciências e Engenharia. São Paulo: Escola Politécnica da USP, 2013.

11. NASCIMENTO, S. S. Protagonismo juvenil e inovação no desenvolvimento de projetos educativos. In: M. A. Moura (Org.). Educação científica e cidadania: abordagens teóricas e metodológicas para a formação de pesquisadores juvenis. Belo Horizonte: Editora da UFMG, 2012.

12. RIBEIRO, Z. L., CAMARGO, A. F. Percepção ambiental - uma análise do uso de figuras representativas da problemática ambiental. Cuiabá: Universidade Federal de Mato Grosso, 2006.

13. SANTOS, M. Técnica. Espaço e Tempo. Globalização e Meio Técnico Científico Informacional. São Paulo: Ed. Hucitec, 1994.

14. SANTOS, M. A questão do meio ambiente: desafios para a construção de uma perspectiva transdisciplinar. Anales de Geografia de la Universidad Complutense (no15, pp. 695-705). Madrid: Servicio de Publicaciones Universidad Complutense, 1995.

15. SILVA, T. C. O Meio Ambiente na Constituição Federal de 1988. Jus Vigilantibus, 1, 2008.

16. TERAMUSSI, T. M. Percepção ambiental de estudantes sobre o Parque Ecológico do Tietê. Procam: USP, São Paulo, 2008, 105p.

17. TUAN, Y. F. Topofilia: um estudo da percepção, atitudes e valores do meio ambiente. Londrina: EDUEL, 2012.

18. YIN, R. K. Estudo de caso: planejamento e métodos (3a ed.). São Paulo: Bookman, 2003. 